\title{
FUNGSI DAN PERAN KEPEMIMPINAN KIAI DALAM PENGEMBANGAN PONDOK PESANTREN DI PONDOK PESANTREN SUKAMISKIN DAN MIFTAHUL FALAH BANDUNG
}

\author{
Muhammad Abdul Rojak ${ }^{1}$, Iing Solihin ${ }^{2}$, Ahmad Halil Naufal ${ }^{3}$ \\ UIN Sunan Gunung Djati Bandung \\ m.abdul.rojak90@gmail.com, iing.solihin88@gmail.com
}

\begin{abstract}
Kyai is a core factor and a central figure in pesantren because all the organizing of pesantren is centered on him. Individual-charismatic leadership in pesantren for certain purposes is needed, but at the same time can also be a weakness of pesantren. Thus, kyai's functions and leadership roles are seen as important to answer the challenges of the times. Pondok Pesantren Sukamiskin and Miftabul Falah are experiencing developments based on the strong leadership role of kiai in pesantren. The purpose of this research is to find out the functions and leadership roles of kyai in sukamiskin boarding school and Miftabul Falah Bandung. This study uses qualitative descriptive methods. The result of this study is known that Pondok Pesantren Sukamiskin and Miftahul Falah have undergone a leadership transformation by applying the tradition of leadership kyai pesantren which aims to develop pesantren. From the existing thing that kyai leadership role has occurred by not eliminating the characteristics of pesantren.
\end{abstract}

Keywords: Functions and Leadership Roles, Kyai, Boarding School

\begin{abstract}
Abstrak : Kyai merupakan faktor inti dan figur sentral di pesantren karena seluruh penyelenggaraan pesantren terpusat kepadanya. Kepemimpinan individual-karismatik dalam pesantren untuk kepentingan tertentu sangat dibutuhkan, namun sekaligus juga dapat menjadi kelemahan pesantren. Dengan demikian, Fungsi dan peran kepemimpinan kyai dipandang penting untuk menjawab tantangan jaman. Pondok Pesantren Sukamiskin dan Miftahul Falah mengalami perkembangan yang berdasarkan akan kuatnya peran kepemimpinan kiai di dalam pesantren. Tujuan dari penelitian ini adalah untuk mengetahui fungsi dan peran kepemimpinan kyai di pondok pesantren Sukamiskin dan Miftahul Falah Bandung. Penelitian ini menggunakan metode deskriptif kualitatif. Hasil dari penelitian ini diketahui bahwa Pondok Pesantren Sukamiskin dan Miftahul Falah telah melakukan transformasi kepemimpinan dengan menerapkan tradisi kepemimpinan kyai pesantren yang bertujuan mengembangkan pesantren. Dari hal yang sudah ada bahwa peran kepemimpinan kyai telah terjadi dengan tidak menghilangkan ciri khas pesantren.
\end{abstract}

Kata Kunci : Fungsi dan Peran Kepemimpinan, Kyai, Pondok Pesantren

Manazhim : Jurnal Manajemen dan Ilmu Pendidikan

Volume 3, Nomor 1, Februari 2021; 83-109

https:// ejournal.stitpn.ac.id/index.php/manazhim 


\section{PENDAHULUAN}

Pesantren merupakan lembaga pendidikan tradisional Islam yang masih bisa survive sampai hari ini. Hal ini berbeda dengan lembaga pendidikan tradisional Islam di kawasan dunia muslim lainya, dimana akibat gelombang pembaharuan dan modernisasi yang semakin kencang telah menimbulkan perubahan-perubahan yang membawanya keluar dari eksistensi lembaga-lembaga pendidikan tradisional. ${ }^{1}$

Kemampuan pesantren untuk tetap bertahan karena karakter eksistensinya,yang dalam bahasa Nurcholis Madjid disebut sebagai lembaga yang tidak hanya identik dengan makna ke-Islaman, tetapi juga mengandung makna keaslian Indonesia (indigenous). ${ }^{2}$ Penyelenggaraan pesantren berbentuk asrama yang merupakan komunitas tersendiri di bawah pimpinan kyai dibantu beberapa ustadz yang hidup bersama di tengah para santri, dengan bangunan masjid sebagai pusat kegiatan peribadatan keagamaan dan sekaligus tempat belajar mengajar, serta pondok-pondok sebagai tempat tinggal para santri. Mereka hidup bersama-sama antara kyai, ustadz, santri serta pengasuh lainnya, sebagai satu keluarga besar. ${ }^{3}$

Sudah menjadi common sense bahwa pesantren sangat identik dengan figur kyai pimpinan atau pengasuh pesantren. Kyai merupakan faktor inti dan figur sentral di pesantren karena seluruh penyelenggaraan pesantren terpusat kepadanya ${ }^{4}$.Sering kali kyai juga merupakan pendiri pesantren, sehingga perluasan dan penentuan corak pesantren sangat bergantung pada kecakapan dan keahlian kyainya. ${ }^{5}$ Kyai juga sumber utama apa yang berkaitan dengan soal kepemimpinan, ilmu pengetahuan, dan misi pesantren yang cenderung tidak mengikuti suatu pola tertentu ${ }^{6}$. Keadaan inilah yang membangun pola kepemimpinan sentralistik kyai dalam mengasuh dan mengelola pesantren. Kedudukan kyai yang sangat kuat dan menentukan ini

1 Azyumardi Azra, Pendidikan Islam: Tradisi Dan Modernisasi Menuju Milenium Baru (Jakarta: Logos Wacana Ilmu, 1999), hlm. 95

${ }^{2}$ Nurcholis Madjid, Bilik-Bilik Pesantren: Sebuah Proses Perjalanan (Jakarta: Paramadina,1997), hlm.3.

${ }^{3}$ Mastuhu, Dinamika Sistem Pendidikan Pesantren Suatu kajian Tentang Unsur dan Niali Sistem Pendidikan Pesantren (Jakarta: INIS, 1994), hlm. 6.

${ }^{4}$ Mastuhu, Memberdayakan Sistem Pendidikan Islam, (Jakarta: Logos Wacana Ilmu, 1999), h.255

5 Manfred Ziemek, Pesantren dan Perubahan Sosial, Terjemahan Burche B. Soendjojo,(Jakarta: P3M, 1986), h. 97

${ }^{6}$ Zamakhsyari Dhofier, Tradisi Pesantren; Studi Tentang Pandangan Hidup Kyai, Jakarta:

LP3ES, 1985), h. 55 
diidentifikasi sebagai kepemimpinan individual kyai, otoriter-paternalistik, dan feudal karismatik, yang menerapkan manajemen alami yang serba "tidak formal",

Jiwa kepimpinan kyai yang ada di pesantren Sukamiskin dan Miftahul Falah sudah menjadi hal bersifat karismatik yang tak bisa ditolak atau dibantah oleh santrisantrinya. Karena seorang kyai memiliki kemampuan dan keahlian yang khusus dalam memimpin. Hal ini sesuai dengan konsep kepemimpinan menurut Kartini Kartono (1994 : 33). Pemimpin adalah seorang pribadi yang memiliki kecakapan dan kelebihan khususnya kecakapan dan kelebihan disatu bidang, sehingga dia mampu mempengaruhi orang-orang lain untuk bersama-sama melakukan aktivitas-aktivitas tertentu, demi pencapaian satu atau beberapa tujuan. C.N. Cooley (1902). Pemimpin itu selalu merupakan titik pusat dari suatu kecenderungan, dan pada kesempatan lain, semua gerakan sosial kalau diamati secara cermat akan ditemukan kecenderungan yang memiliki titik pusat

Fungsi serta tipe kepemimpinan seorang kyai di pesantren Sukamiskin dan Mitfahul Falah masih begitu kental karismatiknya. ${ }^{7}$ Tipe kepemimpinan karismatik ini menurut Kartini Kartono menjelaskan bahwa tipe ini mempunyai daya tarik dan pembawaan yang luar biasa, sehingga mereka mempunyai pengikut yang jumlahnya besar. Kesetiaan dan kepatuhan pengikutnya timbul dari kepercayaan terhadap pemimpin itu. Pemimpin dianggap mempunyai kemampuan yang diperoleh dari kekuatan Yang Maha Kuasa.

Peran kepemimpinan kyai memang sangat terasa dalam perkembangan dunia pesantren. Sebagai contoh, yang dulunya pondok pesantren hanya sebagai lembaga pendidikan dengan menggunakan sistem tradisional (salaf), tapi seiringnya dengan waktu pesantren berubah jadi lembaga pendidikan yang bisa menyesuaikan dengan kebutuhan. Pesantren bersinergi dengan lembaga formal berupa adanya sekolahsekolah seperti Mts dan MA bahkan sampai ada yang menyediakan perguruan tinggi. ${ }^{8}$

Hal ini menjadi daya tarik tersendiri bagi semua orang tua untuk menyekolahkan anaknya sambil mondok di pesantren Sukamiskin dan Miftahul Falah serta hal ini pun semakin jelas dengan semakin banyaknya jumlah santri yang masuk

${ }^{7}$ Data Hasil Observasi pada bulan Agustus 2020

${ }^{8}$ Data hasil Observasi pada bulan Agustus 2020 
dan menetap di pesantren. Santri yang setiap tahunnya jumlahnya semakin besar maka dari segi fasilitas dan sarana prasarana pesantren sudah mengalami kemajuan dan memadai mulai dari kobong. Kamar mandi, madrasah untuk santri mengaji serta bangunan pesantren yang membuat nyaman santri-santri dalam belajar. Selain mempunyai fasilitas yang sudah memadai. ${ }^{9}$

Banyaknya santri yang masuk terkadang hal ini menjadi permasalahan tersendiri untuk pesantren serta kepengurusan santri. Organisasi santri itu mengalami pasang surut karena seorang pengurus itu diambil dari kelas tiga aliyah dan sudah lama disana tetapi setelah mereka keluar mengalami pasang surut kembali. Pengelolaan santri untuk menegakkan kedisiplinan dan kemampuan dalam berorganisasi masih belum bisa sesuai dengan fasilitas pesantren yang cukup memadai. Hal inilah peran seorang pemimpin santri (Rois) dalam bisa mengatur dan mengarah santri-santrinya dan juga bisa membantu peran kyai dalam proses yang terjadi di pesantren. ${ }^{10}$

Berkaitan dengan hal tersebut di atas fenomenanya sangat menarik untuk diteliti, karena banyak perkembangan dan kemajuan tetapi ada hal yang masih perlu diperbaiki dalam pengelolaan santri yang belum begitu baik yang terjadi di Pondok pesantren Sukamiskin dan begitu pula di pesantren Miftahul Falah tidak lepas dari kepemimpinan Kyai yang begitu mempunyai peran yang sangat penting untuk mengembangkan segalanya. Dari hal tersebut jelas bahwa seorang kyai menjalankan fungsi-fungsi kepemimpinan dari fungsi sebagai penentu arah, wakil dan juru bicara organisasi, komunikator yang akftif, mediator hingga sebagai integrator serta menjalankan peran kepemimpinan kyai itu sendiri. Adanya kemajuan dan kemunduran dalam proses pengembangan pondok pesantren Sukamiskin dan Miftahul Falah yang sedang terjadi sekarang tidak lepas dari kepemimpinan Kyai.

${ }_{9}^{9}$ Data Hasil observasi pada bulan Agustus 2020

${ }^{10}$ Data hasil observasi bulan Agustus 2020 


\section{METODE PENELITIAN}

Metode penelitian yang digunakan dalam penelitian ini adalah metode kualitatif deskriptif dan induktif dengan pendekatan fenomenologi sosial. Jenis penelitian ini adalah penelitian naturalistic untuk mengetahui kondisi sesungguhnya (natural/alamiah) yang ada pada suatu objek penelitian di mana peneliti adalah sebagai instrument kunci. Penelitian ini dilaksanakan di Pondok Pesantren Sukamiskin Kota Bandung dan Pondok Pesantren Miftahul Falah Kabupaten Bandung. Jenis dan sumber data menggunakan dua sumber yaitu: a) sumber nonmanusia, termasuk buku-buku primer atau sekunder, majalah, diktat (yang berkaitan dengan manajemen pendidikan pesantren), dan sumber data lain yang dikategorikan non-manusia. b) Sumber data yang berasal dari manusi yaitu: Kyai, pengurus, dan santri di Pondok Pesantren Sukamiskin Kota Bandung dan Pondok Pesantren Miftahul Falah Kabupaten Bandung. Adapun teknik pengumpulan data yaitu: Observasi, Wawancaran, dan Studi Dokumentasi. Langkah-langkah analisis data yang dilakukan yaitu; reduksi data, display data, dan penapsiran data. Untuk menguji keabsahan data-data yang sudah terkumpul dilakukan dengan cara sebagai berikut; 1) Perpanjangan keikutsertaan, 2) Ketekunan pengamatan, 3) Triangulasi, 4) Pengecekan teman sejawat, 5) Kecukupan referensi, 6) Analisi kasus negative, 7) Pengecekan anggota, 8) Uraian rinci, 9) Auditing, dan 10) Auditing kepastian.

\section{HASIL DAN PEMBAHASAN}

\section{A. Fungsi Dan Peran Kepemimpinan Kiai Dalam Pengembangan Pondok Pesantren}

\section{Pesantren Sukamiskin}

Fungsi dan peranan seorang kyai dalam memimpin pondok pesantren sudah mengalami banyak perubahaan sehingga hal ini mengubah fungsi dan peranan seorang kyai corak pesantren Sukamiskin yaitu pesantren yang didalamnya ada madrasah formal yaitu Tsanawiyah dan Madrasah Aliyah. Dengan kondisi ini membuat peran kepemimpinan kyai harus ekstra keras mengelola pesantren dengan 
baik dan bijak. Dari beberapa fungsi-fungsi kepemimpinan ada beberapa yang dilaksanakan didalamnya.

Pemahamaan tugas kepemimpinan Kiai adalah hanya mendidik santri-santri yang ada dipesantren serta menjadi mereka sebagai teman atau patner. Kyai dengan santri tidak ada rasa saling jeda atau pemisah. Peran kyai di pesantren Sukamiskin secara simbol tidak terlihat tetapi bersifat nyata dalam peranannya. Kepemimpinan Kyai yang sebagai penentu arah di pesantren itu jelas dengan masih menerapkan kurikulum pembelajaraan salafiyah walaupun ada sekolah didalam pesantrennya. Beberapa dayayang ada di pesantren Sukamiskin diantaranya ${ }^{11}$ bahwa seorang kyai tidak mau difigurkan.

Hal inipun berpengaruh kepada cara merumuskan visi-misi pesantren Sukamiskin. Melihat kondisi santri dan lingkungan yang sudah harus berubah dengan adanya lembaga pendidikan formal. Maka kepemimpinan Kyai hanya satu menekankan pada akhlak dan prilaku yang lebih baik. Pengambilan keputusan yang menjadi fungsi kepemimpinan Kyai di pesantren Sukamiskin lebih kepada tindakantindakan. Misalnya santri diajak membacakan surat-surat amalan setelah shalat berjamaah maka secara langsung Kyai melaksanakan bersama-sama dengan santri tanpa ada harus penekanan lebih kepada kesadaran santri ${ }^{12}$. Hal itu dilakukan kyai mempunyai tujuan mudah-mudahan santri yang ada di pesantren Sukamiskin semakin pintar dan baik.

"Santri-santri diajak untuk membacakan Surat Kahfi, Al Waqiah, ArRohman setiap setelah shalat Subuh adalah tujuannya supaya mereka betah tinggal di pesantren dan dipermudah dalam belajar serta semakin baik akblaknya"13

Tanggung jawab kyai sebagai pimpinan di pondok pesantren Sukamiskin sudah jelas akan perannya. Kyai tidak mau memerintah secara langsung melainkan beliau memberikan contoh terlebih dahulu dan santri-santri yang lainnya secara sadar menjalankan sesuai apa kyai contohkan sebelumnya.

${ }^{11}$ Data Hasil Wawancara dengan KH. Abdul Aziz Haedar pada bulan Agustus 2020

${ }^{12}$ Hasil Observasi Terhadap Kegiatan Kyai pada bulan Agustus 2020

${ }^{13}$ Hasil wawancara dengan Kyai pada bulan Agustus 2020 
Banyak permasalahan yang ada di pesantren Sukamiskin mulai dari masalah sarana prasarana yang belum memenuhi dengan jumlah santri yang terus bertambah serta masalah santri dengan latar belakang yang berbeda dan masalah-masalah yang bersifat kebutuhan santri seperti air. Sosok kyai menjadi orang yang lebih aktif dalam menyelesaikan dan memberikan jalan keluar. Kepemimpinan beliau yang langsung turun kelapangan merupakan sebuah fungsi konsultatif secara nyata dengan perbuatan.

Peran kepemimpinan kyai terhadap permasalahan yang ada di pesantren Sukamiskin sangat berpengaruh dan benar-benar dibutuhkan untuk memecahkan masalah yang ada di pesantren. Permasalahan akan santri-santri yang bermasalah Kyai langsung turun langsung dalam menyelesaikannya. Salah satu permasalahannya ialah akan tidak sesuainya jadwal sekolah dengan jadwal pengajaran di pesantren Sehingga kyai memberikan jadwal tambahan untuk mengaji bagi santri yang masuk sekolah siang dan mengaji di pagi hari.

Ini merupakan kemampuan pemimpin mengikutsertakan anggotannya sesuai dengan posisi dan kewenangannya agar berpatisipatif aktif dalam kegiatan organisasi. Figur seorang kyai di pondok pesantren Sukamiskin dalam mengelola pesantren yaitu dengan mengikutsertakan keluarga beliau untuk mengajar santri-santri.semua kelas santri diisi oleh putra putrid Kyai dengan tanggung jawab masing-masing yang berbeda-beda.

Dalam kegiatan lainnya, kyai mengikutsertakan santri-santri yang lebih lama untuk mengurus santri baru. Kyai selalu mengajak santri-santri untuk ikut kesetiap pengajian dari dalam pesantren maupun luar pesantren. Misalkan kalau ada pengaiian mingguan bapak-bapak maka santri yang sudah lama mengikuti pengajian tersebut. Hal ini dilakukan sebagai proses mendidik dan melatih santri-santri.

Dan juga kyai tidak terlalu dominan dalam memerintah atau mengganti posisinya mendayagunakan orang lain selain beliau dan keluargannya. Karena beliau berpendapat bahwa 
"Lebih bagus keluarga sendiri yang diterjunkan dalam mengelola pesantren untuk lebih mudah mengarabkannya dan tidak ada perbedaan paham dalam pengajaraanya". ${ }^{14}$

Maka dalam hal apapun di pesantren Sukamiskin fungsi ini sulit dikembangkan atau diterapkan karena masih kuatnya keluarga kyai ikut langsung dalam pengajaraan santri. Pergantian kepemimpinan yang terjadi di pesantren Sukamiskin terjadi apabila salah satu keluarga pesantren meninggal maka keluarga pesantren yang bisa dan yang cocok untuk memimpin pesantren. Hal ini dilihat dari segala kemampuan kyai tersebut. KH, Abdul Aziz Haedar yang sekarang menjadi pimpinan pondok pesantren Sukamiskin sebelumnya adalah KH. Imam Sonhaji yang wafat pada tahun 2009 maka pergantian pesantren pada saat itu secara alami dipimpin oleh beliau. Hal inilah tidak ada sistem pergantian yang khusus akan pergantian pimpinan pesantren.

Bahkan beliau berkata bahwa "disini tidak ada pemimpin yang khusus seperti pesantren yang lain tetapi disini semuanya bekerja dan siapa saja yang ingin mengurus pesantren dan santri. Sosok beliau sebagai pemimpin di pesantren Sukamiskin tidak ingin terlihat secara dominan. Babkan apabila orang tua santri yang baru ketika menanyakan siapa Kyai di pesantren sukamiskin bampir tidak mengetabui baru setelah beberapa bulan mengetahuinya dari anaknya yang pesantren. ${ }^{15}$ ",

Maka dari hasil penelitian tentang kepemimpinan kyai di pesantren Sukamiskin bahwa KH. Abdul Aziz Haedar memberikan pendapat bahwa tugas pokok seorang kyai adalah

"Tugas yang wajibnya ialah sebagai guru atau pengajar para santri, mengasub santri, mendidik serta harus ikhlas dalam melakukan segalanya dan antara kyai dan santri harus saling menghargai. Kyai harus menghargai santri, santri harus menghargai kyai. Kalau itu semuanya sudah dilakukan maka kesaadaran pun akan muncul.selain itu juga pemimpin kyai harus punya rencana, berani mengeluarkan dana untuk kelangsungan pesantren. "16

\footnotetext{
${ }^{14}$ Hasil Wawancara dengan KH. Abdul Aziz Haedar pada bulan Agustus 2020

${ }^{15}$ Hasil wawancara dengn KH. Abdul Aziz Haedar pada bulan agustus 2020

${ }^{16}$ Hasil wawancara dengan KH. Abdul Aziz Haedar pada bulan agustus 2020
} 


\section{Pondok Pesantren Miftahul Falah}

Kepemimpinan yang terjadi di pesantren Sukamiskin sebelumnya ada sedikit berbeda dengan pesantren Miftahul falah. Ada beberapa yang tidak bisa diterapkan di pesantren Miftahul Falah dikarenakan dengan kondisi pesantren yang berbeda dan keadaan santri pun jauh beerbeda dengan pesantren Sukamiskin. ${ }^{17}$

Hal inilah yang menjadikan visi misi pesantren miftahul Falah tidak lepas dari keputusan kyai yang masih kuat menjaga tradisi pesantren salafiyah dengan tanpa mengadakan sekolah seperti pesantren sukamiskin. Menurut beliau bahwa

"Urusan sekolah itu kembali lagi kepada orang yang ingin sekolah silabkan dan yang ingin pesantren juga silabkan tidak memberatkan satu sama lainnya. Pesantren tidak akan memberatkan bagi santri yang ingin sambil dengan sekolah silabkan tapi itu harus diluar pesantren sekolahnya. Kami ingin santri yang sudah beres di pesantren Miftabul Falah bisa mengamalkan ilmunya untuk masyarakat dan untuk dirinya". 18

Kyai yang lulusan pesantren Miftahul Huda manonjaya ini berkeinginan ingin santri-santri yang beres di pesantrenya menjadi ulama dan kyai di daerah santri masing-masing” Hal inilah yang menjadi rumusan visi misi pesantren seiringan dengan tujuan dan peran pesantren.

Dan sangat penting peranannnya karena seorang kyai harus mempunyai keberanian dalam memimpin dengan memberikan kebijakan yang tepat. KH. Iing Solihin mempunyai prinsip bahwa pesantren tidak boleh dicampur oleh sekolah formal dan kalau ada maka sifat kepesantrenannya akan hilang sendirinya. Maka pesantren Miftahul Falah masih menanamkan sistem salafiyah dalam pengajaraanya maka kebanyakan santri adalah yang khusus pesantren tanpa bersekolah walaupun ada hanya sedikit. Maka dengan itu, visi misi pesantren akan tercapai dengan fungsi pengambilan keputusan ini diterapkan oleh kyai.

Wewenang dan tanggung jawab Kyai dalam perkembangan pesantren Miftahul Falah sangat besar dalam mencapai tujuan pesantren. Kyai dalam ini selain beliau memerintah santri untuk melakukan kewajiban khususnya beliau langsung memberikan contoh kelapangan.

${ }^{17}$ Hasil Wawancara dengan KH. Iing Solihin pada bulan September 2020

${ }^{18}$ Hasil Wawancara dengan KH. Iing Solihin pada bulan September 2020 
"Akang" itu menanamkan nilai-nilai taubid sejak dini kepada santri-santrinya dengan hal yang diperintabkan sebelumnya beliau lakukan terlebih dabulu lalu mengajak kepada santrisantrinya."

Pemberian perintah kepada santri santri yang lain beliau jarang melakukannya tetapi dengan tindakan beliau memberikan contohnya sehingga ini semua terasa tidak ada yang merasa diperintah dan harus memerintah. Hal inipun sama dengan apa yang dikatakan oleh santri -santri yang ada di pesantren Miftahul Falah terhadap sikap kyai dalam menerapkan ini. Beberapa pendapat tentang kepemimpinan kyai di pesantren Miftahul Falah yaitu beliau bijaksana dan perhatian terhadap santrisantrinya serta lebih mengutamakan akan ketauhidan santri santri terutama lebih menekankan pada hal-hal ibadah.

Masalah yang ada di pesantren Miftahul Falah yaitu permasalahan santri baru yang biasanya susah untuk beradaptasi dan juga masalah sampah terutama masalah cara membuang sampah ketempat yang lebih layak ${ }^{20}$. Pihak dewan santri sering melakukan konsultasi akan permasalahan sampah dan tempat sampah supaya tidak menganggu lingkungan pesantren. Ketika penelitian berlangsung di pesantren Miftahul Falah, memang terlihat tempat sampah belum layak karena masih dibuang di pinggir sungai yang suatu waktu bisa mencemari sungai sekitar pesantren.

Dewan santri khususnya Rois sudah berkonsultasi akan permasalahan ini ke kyai dan hal ini tidak mudah karena perlu membutuhkan dana yang lumanyan besar untuk membuat tempat pembakaran atau daur ulang sampah organik maupun non organik. Maka kyai memberikan saran bahwa sampah harus di bersihkan setiap hari oleh santri dan buang ke tempat sementara sambil menunggu pembangunan tempat sampah yang layak. Kyai di pesantren Miftahul Falah sudah memberikan solusi akan permasalahan yang ada di pesantren dengan terus berusaha mencari jalan keluar akan permasalahan itu sendiri.

Dilihat bahwa Pesantren Miftahul Falah dengan mempunyai banyak lulusan dan alumni pesantren yang sudah mempunyai lembaga pendidikan islam di setiap daerahnya masing-masing hal ini merupakan kemampuan kyai dalam memberikan

19 "Akang" Panggilan kepada Kyai oleh santrinya

${ }^{20}$ Hasil observasi dan wawancara dengan rois santri pada bulan September 2020 
tugasnya kepada santri ketika mereka berada di pesantren.kemampuan pemimpin mengikutsertakan santri dalam ikut serta mengurus pesantren jelas menjadi lahan untuk santri belajar cara mengelola santri. Satu sisi bahwa posisi kyai di pesantren Miftahul Falah berbeda dengan pesantren Sukamiskin, figur kyai muncul apabila ada santri baru masuk ke pesantren maka orang tua santri secara lisan menitipkan anaknya ke kyai. Dengan bahasa lain ialah adanya ijab kobul antara orang tua santri dengan kyai.

Dewan santri diikutsertakan dalam proses penerimaan dan pengelolaan santri di pesantren tidak semuanya dipegang dan diurus oleh kyai. Kyai hanya menyediakan makan untuk santri setiap harinya. Keadaan pesantren berbeda dengan keadaan organisasi atau lembaga lainnya maka sosok kepemimpinan kyai di pesantren Miftahul Falah begitu masih kuat. Setiap keputusan yang kyai keluarkan kebanyakan itu tidak terlebih dahulu bermusyawarah dengan dewan santri tetapi dewan santri yang mengelola dan mengawasi akan keputusan kyai tersebut.

Pelimpahan tanggungjawab kepada orang lain merupakan cara pemimpin untuk memberikan suasana dinamis di lingkungan pesantren khususnya. Di pesantren Miftahul Falah, kyai memberikan tanggungjawab lebih kepada santrisantri yang lama untuk mengurus dan mengelola santri dan pesantren sesuai dengan kemampuan santri tersebut. Dewan santri berfungsi sebagai organisasi yang posisinya berada di bawah bimbingan kyai dalam perkembanganya dan tugasnya.

Dewan santri diisi oleh santri-santri yang sudah memenuhi syarat menjadi dewan santri. Dewan santri ini mempermudah tugas kyai didalam pengelolaan dan perkembangan pesantren miftahul falah tidak semuanya kyai turun tangan baik itu dari mengurusi sarana prasarana dan santri. Staff pengajar pun kebanyakan dari santri senior yang sudah mempunyai pemahaman lebih dibandingkan santri yang lainnya.

\section{Peran Kepemimpinan Kiai Dalam Perkembangan Pesantren}

Kepemimpinan pesantren secara umum identik dengan kepemimpinan karismatik (charismatic leader) kyai ${ }^{21}$. Kyai merupakan figure sentral yang dipilih, diakui,dihormati,disegani dan ditaati komunitas pesanren dan masyarakat luas.

${ }^{21}$ Baca Tipe Kepemimpinan karismatik 
Sebagai pemimpin informal kyai mempunyai wibawa dan pengaruh yang tidak dibatasi aturan-aturan formal sehingga pendapatnya selalu dibenarkan dan dihargai.

Pondok pesantren Sukamiskin Bandung dan pesantren Miftahul Falah mengarahkan pengelolaan pesantren berbasis manajemen dengan memadukan tradisi kepemimpinan pesantren dan mekanisme manajemen. Tradisi pesantren yang masih kuat karena status kyai masih di munculkan. Kepemimpinan di pesantren Sukamiskin kadang tidak ada jelasnya siapa yang menjadi kyainya karena pesantren Sukamiskin dikelola oleh keluarga pesantren walaupun demikian kepemimpinan saudara yang lebih tua menjadi pemimpin pesantren sedangkan pesantren Miftahul Falah mempunyai figure kyai yang masih kuat.

"Di pesantren tidak ada yang khusus pemimpinnya disini siapa saja yang mau mengurus santri dan ikblas. Bedanya Pesantren Sukamiskin dan yang lain tidak ada kyai yang difigurkan malahan orang tua santri baru tidak mengetahui kyai pesantren ini",22

Selain itu juga, dengan tidak ada aturan yang jelas akan peraturan pengalihan kepemimpinan di pesantren Sukamiskin mengakibatkan tidak ada bahasa saling merintah atau dibawahi semuanya bekerja bersama-bersama. Hal juga sama dengan yang terjadi di pesantren Miftahul Falah kyai langsung turun kelapangan dalam segala hal.

"Pesantren Sukamiskin tidak menekankan kepada santri untuk melakukan kewajiban melainkan ingin mengetahui kesadaran santri-santri itu seperti apa. Dengan kesadaran semuanya akan terasa ikhlas dengan tanpa ada paksaan tetapi saya menekankan bahwa mereka tinggal di pesantren bukan ngekos di pesantren ada kewajiban yang harus dilaksanakan ${ }^{, 23}$

Untuk pembagian tugas dalam pengelolaan pesantren tidak ada tugas khusus bagi kyai karena kyai diposisikan sebagai orang yang mendidik dan mengarahkan santri yang ingin belajar di pesantren Sukamiskin dan Miftahul Falah. Tidak ada tugas yang jelas dalam mengelola pesantren Sukamiskin dan Miftahul Falah ini walaupun demikian semua proses pengelolaan pesantren berjalan dengan baik.

22 Wawancara dengan KH.Abdul Aziz Haedar pada bulan Agustus 2020

${ }^{23}$ Wawancara dengan KH.Abdul Aziz Haedar pada bulan Agustus 2020 
Fungsi dan peran kepemimpinan kyai di pesantren Sukamiskin ini bersifat tidak sentralistik melainkan bersifat bersama-sama karena semuanya dikelola oleh keluarga pesantren yang mempunyai tugas masing-masing tetapi pesantren Miftahul Falah bersifat sentralistik semua keputusan berada di tangan Kyai walaupun sekalisekali pengurus santri.

Gambaran kepemimpinan yang terjadi di pesantren Sukamiskin agak jauh berbeda dengan pondok pesantren Miftahul Falah. Seorang figure kyai di pesantren Miftahul Falah lebih difigurkan karena posisinya tunggal. Kepemimpinan Kyai lebih dominan dibandingkan keluarga dimana seorang kyai bisa memutuskan sebuah kebijakan dan keputusan sesuai keinginan Kyai itu sendiri.

Hal ini dikarenakan keluarga kyai lebih memilih membuat pesantren baru ini juga karena atas ijin kyai supaya bisa menyebar pesantren dimana-mana. Adapun anak yang lebih tua yang tinggal di area pesantren dan membantu kyai apabila kyai ada halangan dan tidak bisa mengajar santri-santri maka putra kyai yang menggantikannya.

Dari gambaran kepemimpinan seperti diatas pasti akan mempengaruhi sebuah perkembangan yang terjadi di pesantren Sukamiskin dan Miftahul Falah. Pesantren Sukamiskin yang mempunyai lembaga pendidikan formal jelas akan mengalami perkembangan dari segi jumlah santri, sarana prasarana dan sistem pendidikan yang lebih dikuatkan untuk menunjang kualitas santri yang diharapkan. Tetapi ada hal yang tidak bisa dilakukan ialah dengan pengawasan santri-santri yang sudah lulus di pesantren tersebut. Kurangnya koordinasi alumni dengan pihak pesantren sehingga mengakibatkan alumni-alumni pesantren Sukamiskin tidak bisa dipantau bagaimana perkembangannya di luar pesantren. Banyaknya perubahaan jadwal yang begitu padat sehingga mengakibatkan santri harus bisa mengatur jam belajaranya antara sekolah dan pesantren dari pagi hari hingga malam.

Pesantren Miftahul Falah mempunyai perkembangan dari segi sarana prasarana dan sistem yang digunakan masih kuat kesalafiyahnya dengan tidak ada pengaruh sekolah formal di dalam pesantren. Ada hal yang lebih ialah dengan banyaknya waktu untuk santri belajar ilmu-ilmu agama secara fokus karena mereka hanya fokus belajar ilmu agama. Dan secara alumni pun pesantren Miftahul Falah 
bisa mengkoordinir dengan baik apalagi bagi alumni yang sudah mempunyai pesantren di daerahnya masing-masing. Untuk mengetahui sejauhmana kepemimpinan Kyai di pesantren Sukamiskin dan Miftahul Falah bisa dilihat dari segi:

a. Pengelolaan Pondok Pesantren Sukamiskin dan Pesantren Miftahul Falah

Pengelolaan pesantren yang umumnya bercorak alami dan serba tidak formal, termasuk pola pewarisan pergantiaan kepemimpinan pada perkembangannya justru mengancam eksistensi pesantren di masa depan. Dengan pola kepemimpinan Kyai dalam pesantren yang bersifat patrimonial dihadapkan secara prontal dengan pola kepemimpinan dan manajemen modern yang bersifat terbuka. ${ }^{24}$

Berbicara tentang hasil peran kepemimpinan kyai di sebuah pondok pesantren Sukamiskin dan Miftahul Falah itu bisa dilihat oleh beberapa indikator dan faktor. Perkembangan pondok pesantren bisa dilihat dari tipe pesantren yang bersistem salafiyah atau khalafiyah. Melihat kenyataannya bahwa pondok pesantren salafiyah merupakan lembaga pendidikan alternatif bagi masyarakat tingkat ekonomi menengah kebawah. Dengan biaya relatif terjangkau oleh semua lapisan masyarakat sehingga putra-putri mereka bisa belajar di pesantren. Hal ini bisa dilihat dari jumlah pengeluaran pembiayaan santri di pesantren Sukamiskin dan Miftahul Falah yang berbeda.

Peran kyai di pesantren Sukamiskin dan Miftahul Falah lebih diutamakan untuk bisa mengelola pesantren menuju kearah yang lebih baik dan bisa menyesuaikan dengan jaman. Hal itulah terjadi di pondok pesantren Sukamiskin yang secara pengelolaan masih bisa diatasi oleh Kyai. Dengan mempunyai keinginan besar dalam mengembangkan santri kedepannya serta pesantren yang lebih meningkat juga. Santri-santri yang ada di pesantren Sukamiskin mempunyai potensi yang bisa diunggulkan walaupun kondisi mereka harus bersekolah juga. Jadwal pelajaraan yang begitu padat di pesantren Sukamiskin hal serta di sekolah, pihak pesantren bisa mengelola pesantren dengan baik sehingga tidak ada benturan jadwal antara jadwal pesantren dan jadwal sekolah.

24 Pradjarta Dirdjosandjoto, Memelihara Umat Kyai Pesantren-Kyai Langgar di Jawa, (Yogyakarta: LKiS, 1999), 8 
"Kami sejak subuh hari harus mengikuti banyak kegiatan pesantren dan sekolah. Pulang sekolah setelah makan siang langsung mengaji bingga malam hari pukul 11 an baru bisa istirahat. Kadang ini yang membuat para santri merasa kesulitan untuk membagi jadwal belajar sekolah dan pesantren,"25

Fungsi manajemen pendidikan sedikitnya bisa diterapkan di pesantren Sukamiskin yaitu dengan adanya kegiatan pengarahan(direction), penerapan (implementation) dan evaluasi(evolution). Figur kepemimpinan Kyai sudah bisa terasa dengan berjalannya sistem yang ada di pesantren Sukamiskin walaupun kyai tidak mau difigurkan oleh santri.

Di pesantren Miftahul Falah tidak jauh berbeda dengan pesantren Sukamiskin. Perkembangan dan pengelolaan pesantren begitu terasa dengan adanya pembenahaan dari sektor sarana prasarana pesantren serta kurikulum salafiyah yang masih terjaga. Pesantren salafiyah mempunyai pengelolaan yang baik termasuk pengelolaan alumni pesantren yang masih terjaga hingga sekarang. Peran kepemimpinan Kyai begitu kerasa oleh alumni yang mempunyai atau mendirikan pesantren baru di daerahnya dengan mengirimkan santri yang ada di pesantren Miftahul Falah ke pesantren-pesantren yang alumni dirikan dengan adanya pengawasan dari Kyai. Pengelolaan pesantren yang berjalan inilah menandakan penerapan fungsi dan peran kepemimpinan kyai masih kuat terjaga di pesantren Sukamiskin dan Miftahul Falah.

b. Penerapan Kepemimpinan Pesantren Sukamiskin dan Pesantren Miftahul Falah

Pimpinan pesantren (pada prinsipnya menyeimbangkan peran utama yang dimilikinya yaitu "school manager" dan "aducational leader." 26 Pimpinan pesantren dapat juga didefinisikan sebangai manager, administrator, leader, supervisor,innovator, motivator, dan evaluator. Hal itu semua perlu adanya penerapan yang nyata dalam hal kepemimpinan yang bersifat saja melainkan perlu dalam hal nyata yaitu tindakan.

Penerapan inilah yang menjadi hal yang penting dari berbagai fungsi kepemimpinan kyai di sebuah pesantren. Peran kepemimpinan kyai yang ada di

${ }^{25}$ Hasil wawancara dengan Rois Rohmatilah

26 Mulyadi, Kepemimpinan Kepala Sekolah dalam Mengembangkan Budaya Mutu (Malang: UIN Maliki Press,2010) hlm. 33. 
pesantren Sukamiskin dan pesantren Miftahul falah sudah menerapkan fungsi-fungsi kepemimpinan seorang Kiai. Dari peran kepemimpinan Kyai pesantren Sukamiskin dan Pesantren Miftahul Falah bisa berperan sebagai:

(1)Manajer, pimpinan pondok/ Kyai bertindak sebagai pembuat rencana, koordinator kegiatan, pendistribusian tugas, penggerak para guru dan staf, pembina dan pengarah, serta sebagai pengurus.

(2) Sebagai administrator, pimpinan pondok juga bisa bertindak sebagai pengendali kurikulum, personalia, kesiswaan, keuangan, sarana dan fasilitas, dan administrasi secara umum.

(3) Sebagai leader, pimpinan pondok bertugas memotivasi, membina, mengarahkan, menggerakkan, dan bisa meyakinkan.

(4) Sebagai supervisor, ia peka dalam hal mengamati, mengevaluasi, menganalisa, dan mampu memberi solusi.

(5) Sebagai innovator, ia diharapkan mampu mengambil langkahlangkah untuk maju.

(6) Sebagai motivator, ia bisa menjangkau masukan-masukan yang berarti buat para guru, para staf dan pengurus unit-unit lembaga, para santri, masyarakat, bahkan pemerintah.

(7) Sebagai evaluator, pimpinan juga mampu mengendalikan kegiatan, baik yang dilakukan oleh individu maupun kelompok. ${ }^{27}$

Itu semua sudah terlaksanakan dalam keseharian pesantren khususnya kepada santrisantri pesantren Sukamiskin dan Miftahul Falah. Hal ini terasa oleh santri-santri dan alumni-alumni pesantren yang peneliti dapatkan. ${ }^{28}$

Beberapa fungsi tersebut menunjukkan bahwa tuntutan masyarakat terhadap kualitas pendidikan tidak terlepas dari kepemimpinan Kyai sebagai pimpinan pesantren Sukamiskin dan Miftahul Falah dalam mengelola smber daya pendidikan. Sejumlah kajian tentang lembaga pendidikan ini memberi temuan tentang besarnya

27 Abdullah Syukri Zarkasyi, Manajemen Pesantren, 202

${ }^{28}$ Hasil wawancara dengan santri dan alumni pesantren 
kontribusi kepemimpinan pesantren dalam menciptakan perbaikan efektivitas pengelolaan pesantren.

Meskipun keadaan tipe pesantren yang berbeda satu dengan yang lainnya antara pesantren Sukamiskin dan Pesantren Miftahul Falah,namun beberapa faktor yang dapat menjelaskan keberhasilan efektivitas kepemimpinan yang terdiri dari unsur visi, inisiatif, dan kreativitas. Lebih lanjut, Mulyadi mengemukakan -faktor tersebut, yaitu:

1) Berkeinginan dan berhasrat kuat membuat pesantren sehebat yang diimajinasikan.

2) Bertindak proaktif dan cepat dalam mengambil inisiatif.

3) Kreativitas untuk menjadikan diri masuk dalam struktur yang dipperankan dan mereka meminta ketepatan waktu dalam peraturan sesuai yang ditetapkan untuk mengejar apa yang mungkin dapat dicapai dalam tujuan personal sebagai pimpinan pesantren. $^{29}$

Pimpinan pesantren dituntut resonsif terhadap perubahan yang berlangsung cepat. Menyiasati perubahan tersebut, menurut Abdullah Syukri, kyai sebagai pimpinan pesantren yang mengatur, mengendalikan, menggerakkan, dan menggiatkan keseluruhan totalitas kehidupan pondok, perlu memerhatikan hal-hal berikut:

(1) Mengkomunikasikan tujuan dan manfaat yang dieroleh dari perubahan yang setidaknya menggeser sistem yang tidak relevan, sehingga perlu inovasiinovasi sistem yang baru.

(2) Membuat master plan yang ada relevansinya dengan kebutuhan kondisi lembaga pendidikan.

(3) Memobilisasi hasil rancangan untuk diterapkan terhadap para staf dan stakeholder lembaga.

(4) Mengawasi dan mengevaluasi jalannya sistem tersebut sebagai langkah pemastian keberadaan sebuah system.

${ }^{29}$ Mulyadi, Kepemimpinan Kepala Madrasah, 32 
(5) Mempertahankan system yang sudah relevan, apalagi sesuatu yang dianggap prinsipil. ${ }^{30}$

Semua itu sudah terlaksanakan oleh peran kepemimpinan Kyai pesantren Sukamiskin dan Pesantren Miftahul Falah walaupun dengan segala tantangan dan keadaan yang berbeda-beda tetapi mempunyai keinginan yang begitu kuat akan terus mempertahanakn pondok pesantren di tengah-tengah masyarakat sekarang. ${ }^{31}$

\section{B. Faktor-Faktor Terhadap Peran Kepemimpinan Kiai Dalam Perkembangan Pondok Pesantren}

\section{Faktor Penunjang Terhadap Peran Kepemimpinan Kiai Dalam Perkembangan}

Ada beberapa faktor pendukung sebagai aspek peran kepemimpinan Kyai terlihat di pesantren dan juga sebaga sarana untuk mengembangkan pesantren itu sendiri ataupun santri. Fenomena pesantren adanya beragama kondisi saat ini dan hal ini beradaptasi dengan situasi yang berkembang. Pesantren salafi yang masih menggunakan sistem pembelajaraan klasik berbeda dengan pesantren yang menggambungkan antara salafi dan kegiatan pembelajaraan modern dengan adanya lembaga pendidikan formal. Hal ini jelas mempunyai tantangan tersendiri untuk meningkatkan atau mengembangkan pesantren tersebut. Ada beberapa aspek pendukung atau penunjang yang menjadi dasar di pondok pesantren untuk konteks saat ini sebagai berikut:

\section{a. Pondok Pesantren Sukamiskin}

Pesantren Sukamiskin adalah pesantren yang sudah menyelenggarakan pendidikan formal untuk santrinya yaitu dari mulai tingkat MTS dan MA. Kebanyakan santri adalah mereka yang bersekolah di pesantren. Ada beberapa faktor yang menunjang akan peran kyai lebih mudah dalam mengembangkan santrinya dengan kegiatan-kegiatan. Salah satu penunjang peran kepemimpinan kyai yang

30 Abdullah Syukri Zarkasyi, Manajemen Pesantren, 201

${ }^{31}$ Hasil wawancara dengan Kyai pesantren 
terjadi di pondok pesantren Sukamiskin yaitu pertama adanya kegiatan pendidikan Agama. $^{32}$

Menggunakan kitab-kitab kuning menjadi ciri khas pesantren Sukamiskin walaupun berada di tengah-tengah modernisasi dengan adanya sekolah. Sejak awal mula pendirian pesantren Sukamiskin sudah mempertahankan tradisi ini. Ciri khas yaitu dengan menggunakan kitab kuning serta berlugot bahasa sunda yang kental dan asli. Ini salah satu penunjang pendidikan agama yang terjadi di pesantren Sukamiskin. Jelas terlihat di daftar mata pelajaraan yang masih mempelajari kitab-kitab klasik.

Kedua adanya pendidikan dakwah yang menjadi pendidikan tambahan di pesantren Sukamiskin. Ada kegiatan santri yang setiap malam kamis yaitu namanya pertamsilan. Pertamsilan yaitu proses pendidikan dakwah dimana santri belajar menjadi penceramah menyampaikan materi-materi tentang keagamaan.adapun kegiatan pakanci juga merupakan pendidikan dakwah dan seni yang sering dilaksanakan oleh santri-santri pesantren Sukamiskin setiap bulan rabiul awal. Apalagi ada agenda acara santri setiap menjelang bulan ramadhan yaitu adanya imtihan. Imtihan adalah kegiatan tahunan dalam rangka meningkatkan sarana dakwah dan seni santri kepada masyarakat dan alumni-alumni pesantren.acara imtihan untuk tahun ini sudah yang ke-98. Sejarah awalnya ada imtihan di pesantren Sukamiskin ialah ketika pendiri pesantren sukamiskin ingin memodernkan pesantren dengan ada kegiatankegiatan penunjang untuk santri tidak hanya berupa mengaji kitab-kitab kuning saja. Maka pada saat itu salah satu proses memodernkan pesantren yaitu dengan cara mengadakan acara imtihan. Hal ini menjadi agenda wajib bagi pesantren dalam melaksanakan imtihan setiap tahunya walaupun tantangan hiburan dunia luar lebih menarik tetapi imtihan di pesantren Sukamiskin tetap ada hingga sekarang.

Ketiga,pendidikan formal yang ada di pesantren Sukamiskin sudah ada sejak 30 tahun kebelakang yaitu pada tahun 1980an pesantren mulai berani mengadakan lembaga formal sekolah. Awal mula berdirinya terjadi perdebatan dengan pesantren yang waktu itu masih salafiyah dan menganggap pesantren Sukamiskin sudah keluar dari jalur pesantren salafiyah. Dengan tantangan tersebut akhirnya pesantren dan sekolah sampai sekarang masih bisa berkembang dan berdiri dengan jumlah santri

${ }^{32}$ Hasil Studi dokumentasi sejarah pesantren Sukamiskin 
yang semakin tahun semakin bertambah dengan adanya sekolah. Hal ini tidak lepas dari tujuan pesantren dan sekolah saling berkesinambungan. Bahkan sekarang pesantren sukmaiksin tidak hanya Mts saja melainkan sudah mendirikan MA pada.

Keempat, pendidikan seni yang menjadi pendukung dalam pendidikan santri dalam mengembangkan minat bakat santri selain belajar pendidikan agama. Pesantren sukamiskin sudah mengalami hal ini begitu berkembang dalam segi pendidikan seni dengan mempunyai beberapa kelompok music nasyid, qosidah dan marawis yang sudah mendapatkan penghargaan di berbagai ajang perlombaan. Hal inilah yang menjadi perkembangan yang sampai saat ini masih bisa dipertahankan dan dikembangkan kepada santri-santri yang lain.

Hanya dari segi pendidikan yang menjadi faktor pendukung dalam peran kepemimpinan Kyai ialah melainkan pendidikan kepramukaan,olahraga, kesehatan dan keterampilan tidak terlalu diutamakan. Hal ini dikarenakan padatnya jadwal antara sekolah dan pesantren sehingga mengakibatkan kegiatan santri untuk kegiatan tersebut sulit dilaksanakan.

Faktor penunjang lainnya ialah dengan memberdayakan santri dalam berorganisasi khususnya organisasi pesantren yang dipimpin oleh seorang ketua santri dinamakan rois. Santri di pesantren Sukamiskin dilatih untk melatih kesadaran dan tanggungjawab sendiri tanpa harus diperintah oleh kyai. Dengan sebuah kesadaran yang begitu kuat sehingga semuanya akan terasa tidak berat dan saling membantu. Hal ini tidak lepas dari keharusan pesantren Sukamiskin untuk melakukan pemebenahaan internal kelembagaan khususnya dari segi pengorganisasian santri.

Pola kepemimpinan Kiai yang terjadi dipesantren Sukamiskin memiliki kepemimpinan yang tidak mau disebut karismatik. Sosok kyai di pesantren sukamiskin tidak terlalu menonjol bahkan bersifat kekeluargaan. Hubungan Kyai dengan bawahannya tampak lebih bersifat kekeluargaan sehingga kayi mempunyai hak untuk menentukan perjalanan dan perkembangan pesantren sesuai dengan keinginan atau nilai-nilai yang dianutnya. ${ }^{33}$

33 Mujamil Qamar, Pesantren dari Transformasi Metodologi Menuju Demokratisasi Institusi, Jakarta : Erlangga, 2005. Hlm.38 
Pondok pesantren Sukamiskin tidak terlalu menggunakan sistem kepemimpinan tunggal kyai yang berkesan pesantren adalah milik pribadi kyai sehingga kepemimpinan yang dijalankan adalah kepemimpinan individual. Walaupun ada sosok Kyai tetapi segala keputusan itu bersifat keluarga pesantren yang menentukan dan sistem kepemimpinan kyai yang terjadi di pesantren Sukamiskin akan berlangsung lama karena mengikuti tradisi pesantren yang dipegang oleh pihak keluarga yang lebih tua.

Untuk peran kepemimpinan Kyai di pesantren Sukamiskin tidak jauh berbeda dengan peran kyai di pesantren salafiyah. Seorang kyai sama berperan aktif dalam pemberian pengajaran dan pendidikan kepada santri-santrinya.

\section{b. Pondok Pesantren Miftahul Falah}

Faktor pendukung terhadap peran kepemimpinan di pesantren Miftahul Falah ialah sistem pesantren yang masih kuat akan salafiyahnya. Santri lebih fokus akan belajar ilmu-ilmu agama tanpa ada campuran ilmu umum. Cara kyai untuk mengarahkannya pun lebih mudah karena mereka akan fokus terhadap pelajaranpelajaran pesantren. Sosok Kyai yang menjadi pemimpin tunggal mempermudah kyai untuk menentukan kebijakan yang diinginkan. Tidak ada pihak lain yang ikut campur akan pengelolaan pesantren yang dipimpinnya.

Dari jumlah santri yang tidak terlalu banyak hal inipun mempermudah kyai untuk mengatur santrinya dan mengajar di kelas-kelas. Dengan masih adanya santri yang lama tinggal di pesantren ini juga menjadi hal yang sangat membantu kyai dalam segala aktifitasnya. Santri senior itu membantu kyai dalam mengurusi santri-santri di bawahnya. Tugas seorang kyai tidak terlalu diberatkan dengan harus terjun langsung kepada santri-santri tetapi dengan adanya santri-santri yang lebih lama semuanya menjadi terasa ringan.

Adanya dukungan dari masyarakat sekitar pesantren Miftahul Falah terhadap pesantren, ini selalu menjadi hal yang sangat dibutuhkan apabila pesantren mengadakan pembangunan sarana prasarana. Masyarakat dengan suka rela membantu dalam segala hal. Hal itu tidak terlepas dari peran Kyai dalam membina pesantren dan masyarakat sekitar. 


\section{Faktor Penghambat Terhadap Peran Kepemimpinan Kiai Terhadap Perkembangan}

Selain faktor penunjang akan perkembangan pondok pesantren, ada juga beberapa faktor penghambat terhadap peran kepemimpinan kyai di pesantren. Hal ini dikarenakan adanya kondisi yang berbeda di setiap pesantren yang ada.

a. Pondok Pesantren Sukamiskin

Sebagai yang kita ketahui bahwa tantangan pondok pesantren pada saat ini sangatlah komplek. Banyak tantangan-tantangan yang harus dihadapi oleh pesantren yang masih menggunakan sistem tradisional/salafiyah. Hal inilah yang akan menjadi tantangan dan permasalahan yang harus di tanggapi oleh pesantren dengan cepat.

Ada beberapa tantangan secara umum untuk pesantren diantaranya ialah tantangan ero globalisasi, perubahaan manajerial dan pembiayaan pesantren. Menjawab semua tantangan tersebut pesantren Sukamiskin mempunyai cara khusus yaitu dengan melaksanakan pendidikan formal bahasa Arab dan Inggris sebagai bekal santri dalam mengahadapi tantangan era globalisasi yang mana bahasa asing sudah menjadi kebutuhan khsusnya bahasa Inggris. Selain itu juga pembehanahaan manajerial dalam pesantren sudah mulai ditingkatkan dengan sebaik mungkin mengdata santri-santri dan hal apapun dalam manajemen data yang rapih. Adanya sekretariat untuk dewan santri agar lebih bisa menjalankan organisasi pesantren serta kyai lebih mempunyai inisiatif yang jauh kedepan. Salah satunya dengan memperbaiki semua sarana prasarana pesantren terlihat lebih mewah dan rapih supaya tidak terlihat kekumuhan pesantren.

Untuk permasalahan pembiayaan pesantren Sukamiskin tidak menjadi hambatan karena mempunyai dana yang cukup untuk pengelolaan pesantren itu sendiri. Bahkan proses pembangunan pesantren pun berasal dari biaya keluarga pesantren dan sisanya dari infaq-infaq orang tua santri.

Walaupun tantangan yang paling kerasa dari pesantren Sukamiskin dan mempunyai tantangan yang baru. Tantangan salah satunya ialah jumlah santri dan latar belakang santri itu sendiri. Tantangan pesantren Sukamiskin ialah santri yang masuk ke pesantren Sukamiskin ialah mereka yang bukan dari keluarga yang paham 
akan keagamaan. Kalau dulu santri yang tinggal di pesantren Sukamiskin ialah anakanak yang menjadi alumni pesantren atau anak-anak kyai di daerahnya sehingga dalam mendidik lebih mudah karena ada dasar agamanya. Tetapi sekarang santrinya mereka yang benar-benar dari awal untuk memahami agama dan mencetak kepribadian dari nol oleh kyai.

Kyai harus lebih ekstra dalam mendidik mereka dari segi hal baik itu dari segi ibadahnya, tingkah lakunya serta pemahamaan dalam ilmu-ilmu agamanya. Latar belakang keluarga yang sudah berbeda-beda inilah yang menjadi tantangan kyai dalam mendidik santri demi keberlangsungan pesantren pada saat ini. Sekarang Kyai turun langsung kelapangan bahkan menurut Kyai pesantren Sukamiskin ibarat mendidik anak kecil yang dari nol lagi dengan sikap bawaan dari rumah mereka yang jauh dari nilai-nilai islami. ${ }^{34}$

Ada hal juga kurangnya tenaga pengajar ${ }^{35}$ yang ada di pesantren Sukamiskin sehingga ada beberapa guru yang mengajar dengan beberapa kitab. Dewan pengajar yang diambil dari keluarga hampir semuanya karena dari satu sisi menjadikan arah pesantren jelas dan tidak ada paham baru atau pertentangan di pesantren Sukamiskin. Sehingga semua keluarga pesantren ikut turun mengajar walaupun masih dalam kekurangan. Makanya keluarga pesantren yang sudah menikah diusahakan tinggal di area pesantren supaya masih bisa membantu kyai dalam mengajar santri-santri yang semakin tahun semakin meningkat.

Selain itu juga, faktor penghambat terhadap peran kyai ialah tidak adanya santri yang lebih senior ${ }^{36}$ ( santri takhasus) yang mana waktu dulu masih banyak sehingga ketika kyai ingin minta bantuan lebih mudah tetapi sekarang sulit. Hal ini dikarenakan santri-santri yang ada di pesantren Sukamiskin semuanya mereka yang bersekolah MTs dan MA. Melihat kondisi ini kyai turun langsung apalagi dalam urusan mengurusi perairan dan hal-hal lainnya.

\footnotetext{
${ }^{34}$ Hasil wawancara dengan KH. Abdul Aziz Haedar pada bulan Agustus 2020

${ }^{35}$ Hasil wawancara dengan santri \& Kyai pada bulan Agustus 2020

${ }^{36}$ Hasil wawancara dengan KH. Abdul Aziz Haedar pada bulan Agustus 2020
} 
b. Pondok Pesantren Miftahul Falah

Faktor penghambat akan peran kepemimpinan kyai di pesantren Miftahul Falah ialah sudah mulai berkurangnya masyarakat untuk memasukan anaknya ke pesantren. Banyak orang tua yang lebih memilih sekolah formal dibandingkan berkeingian anaknya untuk menjadi penerus ulama atau kyai. ${ }^{37}$ Adapun santri yang masuk masih usia kecil kebanyakan ialah lulusan SD bahkan Lulusan SMP. Hal inilah yang menjadi tantangan pesantren Miftahul Falah untuk mendidik mereka dan memberikan pengajaran secara bertahap dengan dasar-dasar keagamaan yang jelas karena mereka masih kosong akan pendidikan agama. ${ }^{38}$ Untuk perubahaan pesantren dengan adanya sekolah menurut kyai bahwa itu bukan jadi tantangan serius karena pesantren Miftahul Falah mempunyai prinsip yang kuat akan sistem salafiyahnya.

"Jika di pesantren ada sekolah formal maka akan bilang kekbusyuan santri dalam belajar ilmu agama dan akan hilang nilai-nilai pesantrennya yang ada hanya tinggal simbolnya saja". 39

Maka dari itu kyai harus bisa menyesuaikan dengan perubahaan jaman dengan tidak menghilangkan eksistensi pesantren. Pengaruh lingkungan pesantren Miftahul Falah yang berdekatan dengan pesantren lain yang berbeda karakter pesantren tasawuf) yang selalu ikut campur dalam urusan pesantren. Terutama masjid pesantren Miftahul Falah merupakan masjid jami’ yang suka dijadikan tempat untuk shalat Jum'at. Yang dimana pengeras suara tidak dikenankan untuk dinyalakan sehingga hal ini sulit untuk dihilangkan. Walaupun dengan pengeras suara warga yang ada di sekitar pesantren akan tahu adzan dan yang lainnya. Oleh karena itu, kyai tidak mau untuk menjadikan itu permasalahan walaupun keinginannya ingin mengsyiarkan pesantren.

Dari hal itulah tantangan-tangan pesantren Sukamiskin dan pesantren Miftahul Falah mempunyai persamaan yaitu berupa latar belakang santri dari keluarga yang berbeda-beda akan paham agamanya. Inilah menjadi beban berat pesantren dalam mendidik santri-santri menjadi kepribadian yang berdasarkan nilai-nilai Islam.

\footnotetext{
${ }^{37}$ Hasil wawancara dengan KH.iing solihin pada September 2020

${ }^{38}$ Hasil wawancara dengan KH.Iing Solihin pada September 2020

${ }^{39}$ Hasil wawancara dengan KH.Iing Solihin pada September 2020
} 


\section{KESIMPULAN}

Fungsi dan peran kepemimpinan Kyai dalam perkembangan pondok pesantren Sukmaiskin dan Miftahul Falah sudah mengalami percapaian fungsi dari kepemimpinan. Ada beberapa hal yang perlu ditingkatkan lagi dalam peran kepemimpinan kyai untuk perkembangan pesantren.

1. Fungsi dan Peran Kepemimpinan Kiai dalam perkembangan pondok pesantren Sukamiskin dan Miftahul Falah sudah dilaksanakan oleh kyai masing-masing pesantren. Dalam beberapa hal penerapan fungsi ini sudah membuat banyaknya perubahaan yang begitu nyata di pesantren Sukamiskin dan Miftahul Falah. Fungsifungsi yang sudah terlaksanakan diantaranya fungsi kepemimpinan dalam pengambilan keputusan. Kiai memberikan kebijakan yang menjadi dua cara pertama kyai mengambil keputusan sendiri secara langsung tanpa ada ikut campur yang lain,hal ini apabila keputusannya berkaitan dengan masalah prinsip pesantren. Cara kedua memutuskan suatu kebijakan dengan cara turun langsung kelapangan memberikan contoh langsung kepada santri-santri dengan tidak ada rasa memerintah ke santri melainkan langsung. Fungsi instruktif seorang kyai walaupun posisinya begitu berkuasa di pesantren tetapi tetap menggunakan cara-cara yang baik dalam memerintah bawahannya. Dengan menggunakan bahasa halus dan tidak menyinggung bawahannya akan menjadikan fungsi ini tidak terasa paling berkuasa dalam memerintah.

2. Faktor yang menunjang terhadap peran kepemimpinan Kiai dalam perkembangan pondok pesantren Sukamiskin dan Miftahul Falah.

Dalam mendukung penerapan peran kepemimpinan kyai di sebuah pesantren maka ada beberapa hal yang perlu diperhatikan. Kegiatan-kegiatan penunjang yang menjadi cara untuk mengembangkan pesantren dalam hal apapun. Kegiatan harian, mingguan dan bulanan akan menjadi hal yang bisa mendukung kyai dalam membina santrinya. Pesantren tidak hanya mempelajari ilmu agama saja melainkan pesantren sekarang harus bisa menyesuaikan dengan kebutuhan masyarakat yang terus berkembang. Maka pesantren menyiapkan pendidikan-pendidikan umum dan pendukung akan perkembangan santri. Pendidikan dakwah, seni, ketrampilan serta pendidikan formal dll. 
3. Faktor penghambat terhadap peran kepemimpinan Kiai dalam perkembangan pondok pesantren Sukamiskin dan Miftahul Falah. Faktor penghambat yang sudah nyata di depan mata pesantren ialah arus era globalisasi yang begitu pesat di tengahtengah masyarakat. Pesantren harus siap akan tuntutan perubahaan yang terjadi di tengah masyarakat. Perlu adanya perubahaan-perubahaan yang bisa menyesuaikan dengan kebutuhan pesantren yang bisa dilihat keberadaannya dan bisa bersaing dengan lembaga-lembaga lain dalam mendidik anak bangsa. Maka pesantren harus yang lebih terdepan dalam menghadapi tantangan ini. Tantangan era globalisasi inilah yang mengharuskan adanya perubahaan dalam manajemen pesantren. Manajerial pesantren harus bisa disesuaikan dengan pendidikan formal disamping tidak hilang prinsip-prinsip pesantren. Dengan perubahaan manajerial yang perlu diterapkan di pesantren kadang menjadi penghambat bagi pesantren tersebut karena kurang siapnya kyai untuk hal itu. Kiai lebih nyaman dengan cara memimpin pesantrennya sesuai dengan kehendaknya sendiri tanpa adanya perubahaan manajerial yang membuat semakin rumit bagi pesantren.

Selain itu juga faktor yang menjadi penghambat lainya ialah akan pembiayaan pesantren yang belum mempunyai sumber pembiayaan yang kuat. Tuntutan untuk merubah manajerial pesantren adalah adanya pembiayaan yang kuat. Untuk membangun dan menambah sarana prasarana pesantren seperti bangunan,masjid dan hal-hal lainnya dibutuhkan pembiayaan yang cukup besar.

4. Hasil pelaksanaan fungsi dan peran kepemimpinan Kiai di pondok pesantren Sukamiskin dan Miftahul Falah

Hasil dari sebuah penerapan fungsi dan peran kepemimpinan Kiai di pondok pesantren Sukamiskin dan Miftahul Falah ialah dengan adanya pengelolaan pesantren dengan baik. Dengan pengelolaan pesantren inilah menandakan adanya hasil dalam pelaksanaan peran kepemimpinan kyai dengan baik. Ada beberapa indikator bahwa fungsi dan peran kepemimpinan kyai berjalan dengan baik di pesantren ialah adanya sektor pembenahaan dari sarana prasarana, masih kuatnya kurikulum yang diterapkan di pesantren sebagai cirri khas di tengah-tengah tuntutan jaman dan menambahkan beberapa hal sebagai kebutuhan tambahan santri di pesantren. Hal lain bahwa fungsi kepemimpinan kyai di pesantren tidak hanya sebagai pemimpin tunggal atau tugasnya 
mengajar dan mendidik santri tetapi bisa berfungsi sebagai manajer, administrator, leader, supervisor, innovator dan motivator. Itu semua perlu ada di dalam peran kepemimpinan kyai di pesantren.

\section{DAFTAR PUSTAKA}

Azyumardi Azra, Pendidikan Islam: Tradisi Dan Modernisasi Menuju Milenium Baru, Jakarta: Logos Wacana Ilmu, 1999.

Nurcholish Madjid, Bilik-Bilik Pesantren Sebuah Potret Perjalanan, Jakarta: Paramadina, 1997)

Mastuhu, Dinamika Sistem Pendidikan Pesantren Suatu kajian Tentang Unsur dan Niali Sistem Pendidikan Pesantren (Jakarta: INIS, 1994)

Mastuhu, Memberdayakan Sistem Pendidikan Islam, (Jakarta: Logos Wacana Ilmu, 1999)

Manfred Ziemek, Pesantren dan Perubahan Sosial, Terjemahan Burche B. Soendjojo,(Jakarta: P3M, 1986)

Zamakhsyari Dhofier, Tradisi Pesantren; Studi Tentang Pandangan Hidup Kyai, (Jakarta:

LP3ES, 1985)

Pradjarta Dirdjosandjoto, Memelihara Umat Kyai Pesantren-Kyai Langgar di Jawa,

(Yogyakarta: LKiS, 1999)

Mulyadi, Kepemimpinan Kepala Sekolah dalam Mengembangkan Budaya Mutu (Malang: UIN Maliki Press,2010)

Mujamil Qamar, Pesantren dari Transformasi Metodologi Menuju Demokratisasi Institusi, Jakarta: Erlangga, 2005. 